\title{
Non só a lingua, tamén a inútil desobediencia nos achega ao que non somos
}

\author{
Antonino NiETo Rodríguez
}

\author{
o poeta \\ mergúllase máis alá da liña do horizonte \\ como os mortos. \\ como as palabras tece pasadizos, vinganzas.. \\ nunca dorme. \\ orfo \\ raiado sempre \\ deconstrúe inmortais tumbas
}

(do poemario debuxas ausentes)

\section{o corpo da risa (a modo de apuntamentos)}

a lingua, como o tempo, reliquias dun pasado que nunca existiu.

a identidade é cousa ou cadea xa prescrita. Agora lévase o descartábel...

contra a maldita morte e a súa ascendencia... estamos ou continuamos vivos: haberá que celebralo...

por se así (borrásemos)borrando a imparábel fervenza de significados, símbolos e demais rendicións, (e así) acadaramos o non lugar da non duración...

que hai de natural no que en nós percibimos ou queren que percibamos como natural?: nada!

Hai imposición, arbitrariedade... o desconsolo propio de aquilo que nos escapa maldicíndonos. E é que aínda na bondade, din, da nosa pertenza a aquela, á natureza -xa ve vostede, de novo imposición e arbitrariedade- se algo nos fai seus, é a necesaria e brutal traición a cantas leis, regulamentos, fervores e alegrías nos constitúan. E nin sequera así poderemos nunca considerarnos libres, isto é, alleos ao seu peculiar e instintivo encadeado: aquilo que transforma en artificio calquera acción ou omisión. Pois é desde o simulacro que voa -son as súas ás o silencio, a repetición sempre distinta do mesmo e a fugaz, por implacábel e inacabábel, variedade na sumisión- que voa, digo, sen variar ou menoscabar o máis mínimo nin a súa condición, nin a súa localización nin ámbito: e é que non hai mapas, senón exercicios de poder... nin maior sangrado que o corazón que che alimenta froito temporal do po: ese territorio ou axente á historia adscrito.

Os 4 xinetes da apocalipse e o papa negro.

Segundo S. Xoán, os 4 xinetes -a día de hoxe, a rendición incrustrada a golpe de identidade en calquera ti, eu, que se prece- os 4 xinetes da apocalipse, digo -a guerra, a peste, a fame e a morte- responderían, insisto, hoxe, á solar danza da anulación das raíces, do mellor do mellor, da cotización especulativa dos elementos - calquera que sexan-, da ancoraxe na nube -fiel servidora do seu amo-e as súas irremediábeis choivas finas, a saber:

A visibilidade intocábel (transparencia),

O corpo insípido (politicamente correcto),

A podremia inodora (a hiperrealidade do impulso electrónico, do virtual: de cidadán a bit)

Sen pegadas nin xeonllos cos que meritoriar a rendición (canto máis saben de ti, menos existes ou máis estás nas súas mans: a información como anulación da identidade... trazo 
que confina a globalización en parque temático (para unha babexante e numeral musculación da alegría)

E serían -eses 4 xinetes e algún máis que de tanta luz, cega- os responsábeis do acervo de bondades que aqueixan ou furan os aínda sempre nacentes ou xa nunca nados

O papa negro?

Unha cultura - esta, a outra, a amante e a sacrificada esposa- que perde o nacido humano entre as pernas da nada máis absoluta:

Nada xa o teu nome -ningún-

Nada o caudal de tempos, resistencias, risos -vertixe, apenas vertixe-

Nada o perdido nin o que aínda está por gañar:

Simples borranchos, lentes, sopa de letras no ermo do nunca

Sendo o nunca ese berce inmenso que te crava ao pé do barro:

Para que xamais te perdas

Para que todas as bocas sexan unha e así a dor se compute sen testemuñas...

Que non é barro nin pé de vasoira nin borrancho na conta do maldito resultado,

Es o non escrito,

$\mathrm{O}$ inexistente,

O non mundo na nudez do berro

Fe, esperanza, caridade: apenas un berro: contra deus, contra o que está aínda por acadar, contra a inexorábel barbarie: a conciencia, a memoria e a morte

Un só dente: o corazón do número

Mil brazos para tan pouca perda, para tanto horror: para que a palabra non disolva o inocente

A lingua, o vento: o lazarillo cego na inmensidade das sombras...

Unha soa lingua

Todas e todo fragmentos de luz na sequidade do silencio máis avarento e impenetrábel:

$\mathrm{O}$ que non responde ao que teimamos por domesticar como vida
Dicimos vida e falamos de combinacións en pantagruélica espiral

Falamos e mandados sempre, conspiramos, non contra o silencio que en todo se entremete ou, aínda peor, que de todo fai pan ou rendición á alza contra a alegría de se recoñecer mortais, non!, falamos e reducimos o misterio a po, a suor da invisibilidade que en todo nome ou esquela se expande, aos pés do aire en perpetua gargallada.

Tocarlle os fociños ao misterio, aí toda a renda e o corazón do tempo

Falar de cultura galega -ou española ou anglosaxona ou asiática ou...-

Eu falaría dalgunhas peculiaridades ou tics, no marco da uniformización xeral. E aínda máis, diría que esas peculiaridades ou tics son o substrato da conformidade que agranda a uniformización á alza

Unha lingua líquida

Uns oceánicos sentidos

Unha torrencial desobediencia, non só contra o calvario, tamén contra a estéril alegría das marxes

trátase de erradicar a morte da face e o mastigado do vivente!

Sabios, non seus, loucos, tratan de disolver a vida para así erradicar a morte: contrapoñen morte contra morte, nos salóns (ou aleróns) do crime

Feridos pola metal virxinidade do nunca bastante, é a súa vacina contaxiar, contaminar... baleirar a palabra de contido e sal

unha lingua multipolar, ás veces incomprensíbel; uns sentidos inconvenientemente descerebrados; nada o sentido común senón é como lacra contra a viralidade da consecuencia!

Todo iso, apenas, para que os nados non falen con deus, para que non se sangren vítimas da verdade: dese privilexio que en nada consinte o condenado, se sabe, ao condenado, nin inferno sequera

E así, enfermos, ricos, valentes na súa cortedade cegadora véndennos, ou nunha deposición de suprema xenerosidade impóñennos, 
xa sabes, que os contos de fadas existen, que a indiferenza como as marcas ou o látego da miseria empequenece a nada: a lingua, tamén

A economía: o ventre do asasino

Agora non se fala, conéctase...

máis alá de todo,

gañado o esquecemento

-pedra,

panca que a deus cronometra-:

a lingua,

saboreado exilio.

(do poemario debuxas ausentes) que dormen as palabras cando din?

que expulsan?

son ventre, estómago

simples contas que o osíxeno fai medrar?

que cobran, de quen?

pagan algo?

retratan, compulsan, descifran:

conseguen

partillan ningún principio

respiran.

coma ti

ou coma min

distribúen cordas.

(do poemario debuxas ausentes) 